\title{
Driving innovation through ambidextrous service provision - long life cycle products in manufacturing contexts
}

Abstract: The aim of this paper is to explore the possibility that continuous improvement rather than radical innovation in the case of long life-cycle products can be consistent with both economic growth and the market drive towards sustainability in some circumstances. Sustainability within this context is defined in terms of extending the new product development (NPD) process to encapsulate cost and waste reduction by continuous incremental innovation and servicing of existing products. Ambidexterity is introduced as the enabler of sustainable service provision within this context. The paper discusses a conceptual framework for driving innovation through ambidextrous service provision and provides an illustrative case to support it. It contributes to the innovation and sustainability literature through acknowledging the importance of both exploration and exploitation within NPD processes, integrating this with sustainable service provision, and with particular reference to Product Service Systems (PSS).

Keywords: product development, long-life cycle, sustainability, product service systems, ambidexterity, conceptual framework 


\section{Introduction}

The aim of this paper is to explore the possibility that continuous improvement rather than radical innovation in the case of long life-cycle products can be consistent with both economic growth and the market drive towards sustainability. Sustainability within this context is defined in terms of extending the new product development process to encapsulate cost and waste reduction by continuous incremental innovation and servicing of existing products (Alting and Legarth, 1995). Service provision is traditionally related to after market, it is however evident that the service component termed, servitization of manufacturing, is growing in many productcentric firms (Baines et al, 2009) and goes beyond these standard aftermarket engagements. In heavy engineering firms, innovation is often related to new product introduction or manufacturing processes and they struggle with service innovation (Kindström and Kowalkowski, 2014).

To explore this challenge, the research question guiding this paper is "In what way can the new product development (NPD) process be refined to ensure sustainable servitization of long lifecycle products within manufacturing environments?" Addressing this question adds to a body of knowledge related to the development of product-service systems. The contribution supports a conceptual framework where we introduce a novel term "ambidextrous service provision" demonstrating how both innovation and sustainable service provision can be integrated with the NPD process.

The paper is structured as follows: a background literature is reviewed in Section 2 to support the development of a theoretical proposition related to ambidextrous service provision within NPD. Literature related to product service systems (PSS), product stewardship, product life cycle, innovation, product development and ambidexterity is introduced. This supports the development of a conceptual framework that expresses how sustainable service provision can be integrated within the NPD process. This theoretical proposition is developed in Section 3 with an integrative framework that systematically links NPD and PSS with long life-cycle product development. The framework is then applied to an illustrative case in Section 4, and Section 5 ties up the analysis with some tentative conclusions. 


\section{Literature Review: Building the theoretical framework}

Service innovation traditionally emphasised development of new service offerings and concepts such as aftermarket service provisions and customer-oriented options (Kindström and Kowalkowski, 2014). To achieve a unified service provision framework firms cannot simply develop one new service after another but need to combine manufacturing innovation with service innovation (Gallouj and Savona, 2010). This requires an integrated approach that merges new services and innovations in other elements of the business model and value network in order to create and capture new value (Nenomen and Storbacka, 2010). It is therefore unsurprising that notwithstanding proven opportunities within service provision for long life-cycle products, the proportion of manufacturing companies making profit through servicing is low (Gebauer and Fleisch, 2007; Kastalli and Looy, 2013). Understanding this phenomenon presents a significant research gap especially as manufacturers become more interested in adding value through service provision (Tucker and Tischner, 2006). The following sections unpack components related to Product Service Systems (PSS) to include sustainability, lifecycle design and product stewardship, innovation and new product development.

\subsection{Product Service Systems (PSS)}

Product service systems (PSS) is an overarching term to describe service provision as a methodology and has been defined as " a system of products, services, supporting networks and system solutions that have the potential to minimise environmental impacts of customer needs and wants" (Mont 2001, p 3), extending the traditional functionality of products by incorporating additional services. For customers, PSS means a shift from buying products to buying services, sharing some of the risks and responsibilities conventionally associated with ownership to the supplier (Mont, 2001). At the same time, the manufacturer improves competitiveness by offering service solutions that ensure the product is continually improved in terms of usage, design and reliability (Baines et al, 2007). Through processes of continuous improvement PSS solutions have a positive economic effect but also have a potential to

minimise environmental impact through improved productivity and reducing waste (Pham and Thomas, 2012).

Adopting such an approach is required to convert a firm from product to a service-centric system, encompassing a value proposition that optimises the customer's business operations 
(Liu et al, 2014). Such business models have the potential to generate a spiral of revenue growth when the product-service provider has the ability to control the cost of the entire value system (Tukker and Tischner, 2006). This can only be achieved, if the manufacturer invests in service specific resources and capabilities (Kastalli and Looy, 2013). In order to prolong a product's life, this stage includes design of maintenance and serviceability. This incorporates technical service strategies that embed flexible individualisation and product enhancement according to individual customer demand. Such technical services contribute to higher productivity and reduce investment costs (Aurich et al, 2006). Total cost of the product is reduced as a result of technical, process and customer knowledge, while know-how and capabilities remain with the manufacturer (Brady et al, 2005). Incremental innovation extends the life of the product, reducing development time and risk. The process is ongoing and in line with current and future customer requirements (Pham and Thomas, 2012).

There are various forms of PSS; the case below is that of a product-oriented PSS where the selling of the original product can be bundled with additional after-sales service such as maintenance, repair, recycling (Burns et al, 2007. P.5). In PSS systems, the manufacturer is motivated to continue to improve the product over time, offering value in use. This can be explained from a sustainability perspective, reducing environmental impact as well as providing the manufacturer with a differentiated product that improves through continuous incremental innovation (Baines et al, 2007; Spangenberg et al, 2010). Incorporating a PSS competitive strategy encourages the manufacturer to focus on delivering knowledge intensive products and services. Such services encapsulate product, process and customer knowledge enabling customization and higher quality (Baines et al, 2007).

By engaging in service activities, the manufacturer becomes better informed of customer needs and in so doing presents possibilities to increase and improve the product offering to the customer (Kastalli and Looy, 2013). Integrated PSS solutions increase value to the customer through lifetime and life-end services bundled with products, thereby changing the focus of the value proposition from manufacturer to solution provider by focusing on services (Manzini and Vezzoli, 2003; Gebauer and Fleisch, 2007). This requires supply chain collaboration during the new product development process, beginning at the product design stage and continuing through to the end of the products life (Liu et al, 2014; Doualle et al, 2016); a system of interacting parts that include people, technology and businesses (Chesbrough and Spohrer, 2006). Despite the fact that services can generate higher margins than products alone, it would 
seem that managers are not fully convinced, partly explaining reluctance to exploit the opportunities of PSS (Grabauer and Fleisch, 2007).

Nevertheless, PSS strategies can be compelling as manufacturing firms find ways to increase involvement externally with customers and partners, as well as modifying internal relationships across business functions (Galbraith, 2002). Accordingly, PSS is a system that requires early customer involvement and can involve changes in organizational structures of the manufacturer (Mont, 2001). According to Kastalli and Looy (2013), over a third of large manufacturing firms offer services (see also Gebauer and Fleisch, 2007). The results of studies on performance can be mixed, though Neely (2008) suggests a U shaped relationships between servitization and performance; positive results re-appearing when there is a critical mass of services achieved and size of the service portfolio increases (Fang et al, 2008).

\subsection{Product Service Systems and Sustainability}

Product Service Systems (PSS) increase customer value by provision of cradle-to-grave product / service offerings (Reim et al, 2015). Such total solutions require firms to adapt from goods to service focused business models (Lightfoot et al, 2013). PSS has been described as a special form of servitization, extending the traditional functionality of a product by incorporating additional services, in order to fulfil need, demand or function (Tukker and Tischner, 2006). PSS represents a path towards sustainable resource use (Stoughton and Votta, 2003) and may resolve sustainability problems by encapsulating economic, environment and social components (Lee et al, 2012).

From an environmental perspective, product oriented services contribute to reduce environmental impact in terms of product usage and increase resource productivity. At the same time, the integration of environmental considerations must be prioritised and considered in the development of the new product (Westkämper et al, 2000). Closed loop practices can include preventative maintenance and retrofitting initiatives early in the product development process (Alting and Jørgensen, 1993). From this standpoint, service may be viewed as systemic, comprising interacting parts where value is created by configuration of resources, people and technology (Chesbrough and Spohrer, 2006). The effectiveness of the NPD depends on sound collaboration with supply chain partners, starting with the design and continuing to the end of the products life cycle (Spangenberg et al, 2010). This responsibility extends both up-stream 
and down-stream (Manzini and Vezzoli, 2003; Alting and Jørgensen, 1993). Life cycle design and product stewardship become key issues, where decisions concerning structures and properties are considered and adjusted throughout the NPD (Liu et al., 2013). These linkages are demonstrated in figure 1.

Much of the literature relating to PSS emphasises how PSS might address social sustainability, for example impact at local level through technical service support could help to secure knowledge intensive jobs, improvements in workplace health and safety would support worker wellbeing (Fraça et al., 2017; Pham and Thomas, 2012; Aurich et al, 2006; Brady et al, 2005). Wider objectives within the sustainability debate are also considered in terms of how to address complex social challenges such as ways to tackle poverty through provision of affordable products, accessible services, improved public infrastructure and "equitable access to the world's resources as a kind of human right to resource use" (Spangenberg et al, 2010, p 1486).

\subsection{Lifecycle Cycle Design and Product Stewardship}

Products in all stages of the life cycle, from raw materials, production, consumption and end of life, can have adverse environmental and social impacts (Maxwell et al, 2006) and PSS support resolutions and mitigating strategies to issues relating to overconsumption of materials and resources (Fraça et al, 2017), such as dematerialisation and closed loop systems (Spangenberg et al, 2010).

Innovation captures the products value in terms of use and end of life management, while enhancing sustainability through reduced environmental impact (Liu et al, 2014). The logic is underpinned by utilising the knowledge of the designer and manufacturer to increase value to the customer and decrease material and other costs as an output of the system (Morelli, 2006; Baines, 2007). Life cycle design strategies considered by the manufacturing industry frequently address contemporary issues related to growth and include the impact on the external environment (Fraça et al, 2017 Aurich et al, 2006). In this sense, the product and service provider take on greater responsibility for the product's full life cycle, include customers early in the design process and facilitate closed-loop systems to minimise the environmental impact of consumption (Brady et al, 2005; Mont, 2001). The earlier the sustainability impact of a system is assessed, the sooner the design can be modified towards improving that impact (Doualle et al, 2016). 
Therefore, adding services to product offerings extends into every part of the value chain encapsulating the life-cycle concept and life-cycle design strategies to incentivise innovation by defining new materials, increasing efficiency and reducing costs (Pham and Thomas, 2012; Maxwell and van der Vorst, 2003). While systematic product design is well established in industrial practice, technical service design is usually detached from product development, resulting in sub-optimisation of strategic resources and lack of support mechanisms at an operational level (Aurich et al, 2006). The conceptual framework offered in this paper resolves this tension (see figure 1).

Friedli (2005) states that to ensure competitive advantage manufacturing companies must innovate in the area of customer support and invest in service related capabilities. This captures the notion of product stewardship, an organisational philosophy and practice that supports ways to extend the life of a product by increasing efficiency, reducing costs and raw material usage, while simultaneously improving product functionality (Mont, 2001).

Product stewardship involves a range of issues related to the environmental performance of products in all life cycle phases, including serviceability and end-of-life planning (Tukker and Tischner, 2006; Maxwell and van der Vorst, 2003). Product stewardship schemes have been widely utilised in large manufacturers such as the electronics and the automotive industry, where design strategy incorporates possibilities for technological innovation (Brady et al, 2005).

Such insights need to be taken into account in the development of the product and this preliminary stage of NPD is where product concept, structure, materials and process alternatives are evaluated and prioritised (Cooper, 2008). Early customer involvement is crucial as detailed knowledge of user activities and future requirements must be designed into the new product (Lightfoot et al, 2013). The importance of customer and supplier relations becomes relevant as the manufacturing firms form close relationships and establish routines and communications. The manufacturer learns from the customer what their functional and environmental needs are and the supplier provides components to meet these requirements (Liu et al, 2014). Such relationships require high levels of engagement, focusing on customer's processes and problems which may increase risk to the service provider (Lightfoot et al, 2013). 
Risk adoption and value creation are essential factors considered in the design of service oriented propositions (Brady et al. 2005; Morelli, 2006)

This is a challenge for organisations that are traditionally production oriented and requires transformational cultural changes to achieve a 24-7 service mind set (Gebauer and Friedli, 2005). Indeed, Gebauer and Friedli (2005) suggest that the majority of managers are not highly committed to customer service, as it involves considerable operational change and companywide implementation. As well as this, difficultly in measuring costs of service provision is a barrier to service execution, although research suggests that services generate significantly higher margins and products (Lightfoot et al, 2013).

Despite this shortcoming, delivering integrated solutions extends the traditional product lifecycle to include activities requiring innovation approaches to creating value for suppliers and customers (Brady et al, 2005). This notion embraces the concept of PSS and links life cycle management and product stewardship in the development of new products (Fraça et al., 2017). Although sustainability has been identified as an important dimension for the development of PSS it is claimed that there is a lack of existing methods and tools to fit the product-service view (Doualle et al, 2016). The presented illustrative case attempts to addresses this gap.

\subsection{Innovation and New Product Development}

According to Teece (1986) innovation and knowledge embedded in processes are difficult to copy and may be a key success factor where the firm already controls many of the essential specialised assets. As technology becomes more complex and industries mature, it is unlikely that such specialised assets are held by a single firm (Petrick and Ecols, 2004). This requires buyers and suppliers to take a longer term perspective, relating to current and new technologies in a more open information sharing network (Kindström and Kowalkowski, 2014; Petrick and Ecols, 2004). Understanding the dynamics of technology evolution allows for short and long term new product investment decisions.

A long term view encourages a firm to invest in sustainable new product development, enhancing core competences, while reducing risk and uncertainty resulting from short-term rate of return decisions (Kindström and Kowalkowski, Sandberg, 2013; Petrick and Ecols, 2004). Such a perspective takes into account a firm's competencies as well as the skills and knowledge available within the supply chain that enables it to offer products and associated 
service rather than product alone (Barnett et al, 2013; Liu et al, 2013). According to some scholars, manufacturing firms are moving towards offering service provision to avoid competing on cost alone (Barnett et al, 2013). It is well documented that this shift is challenging, requiring new ways of working and increased customer focus reflecting interaction within and beyond the firm (Barnett et al, 2013; Spangenberg et al, 2010).

March (1991) stated that for organizations to be sustainable in the long term depended upon the ability to exploit current capabilities, while simultaneously searching for entirely new competences. Literature suggests that there are tensions involved in adopting these two approaches simultaneously due to different knowledge processes, where exploitation hones current knowledge and exploration requires the development of new knowledge (March 1991; Gibson and Birkinshaw 2004). This tension can be resolved by adopting a portfolio approach to NPD where the NPD process moderates diverging requirements of projects and the degree of exploitation and exploration adopted throughout the NPD process varies (Kindström and Kowalkowski, 2014). The term organizational ambidexterity has been used to signify how a firm might manage these pressures (Tushman and O'Reilly, 1996).

\subsection{Driving Innovation through Ambidextrous Service Provision}

Andriopoulos and Lewis (2009) suggest three factors that sustain organizational ambidexterity: namely, a multi-level approach; complementary tactics; and learning synergies. A multi-level approach requires integration at three levels: firm (strategic), project (customer orientation) and individual (personal motivations). Complementary tactics are mechanisms that enable organizations to address both exploitative and explorative activities within the same organization and help to avoid one-sided efforts focusing on either exploitation or exploration (Raisch et al, 2009). Finally, learning synergies sustain ambidexterity, emphasising the interplay between exploitation and exploration. Cohen and Levinthal (1990), describe this as absorptive capacity, that is, the firm's ability to recognise, assimilate and apply new knowledge. Exploitation that transforms and commercialises knowledge is only beneficial if the firm undertakes explorative activities, without which the firm's store of knowledge would erode. At the same time, without exploitation, knowledge may not be fully utilised to be recombined and reconfigured across projects or product iterations (Andriopoulos and Lewis, 2009). Thus, ambidexterity depends on (i) the firm's ability to integrate internal and external knowledge and this relies upon a (ii) combination of external social relations comprising strong and weak ties as well as (iii) internal absorptive capacity (Raisch et al, 2009). 
PSS requires manufacturing firms to engage, not only with customers and suppliers within the firm's immediate environment, but also to draw upon new technologies and knowledge from more distant set of actors and sources (Salge et al, 2013). Such open models advocate innovation strategies that improve existing products and encourage creation of entirely new products (Liu et al, 2013; Tushman and O'Reilly, 1996). PSS literature highlights the need to access external stakeholder competences and develop service related capabilities (Kindström and Kowalkowski, Sandberg, 2013).

From this viewpoint, ambidexterity is an integral capability for PSS implementation to explore customer needs and evaluate consumer segments, new markets and technology (Fraça et al, 2017). An ambidextrous perspective is need to engage in exploratory learning and requires the ability to manage multiple forms of partnerships supporting wide ranging collaborations within the supply chain and with customers (Liu et al, 2013).

Specific processes integrate learning across the firm by making use of experience to reduce costs and develop internal innovation capabilities within the NPD process (Matthews et al, 2015). Research into innovation and knowledge processes stresses the importance of the external acquisition of new knowledge from exploration. The structural design of the NPD process is a critical factor to successful innovation and adopting an ambidextrous approach enables innovation not only in the development stage, but in all phases of the product life cycle, including manufacturing, installation, consumption and maintenance (Martini et al, 2013). PSS enables organizations to be ambidextrous due to simultaneous attention to exploitation and exploration.

Figure 1 illustrates virtuous circles of ambidexterity within the NPD process as cycles continue, reinforce ambidextrous practices and innovative offerings can be developed by recombining and integrating service components and products (Pham and Thomas, 2012). Ambidextrous service provision reduces competition for firm's resources as exploration and exploitation activities become embedded within the NPD process. Using existing capabilities efficiently (exploitation) creates new offerings and market spaces that enhance capabilities (exploration) (Kindström et al, 2013).

Ambidextrous service provision requires a more open approach to innovation. The innovation process and collaboration begin at the design stage and continue through to the end of the product life cycle (Liu et al, 2013). At idea generation and design stages exploration activities are needed to provide flexibility and knowledge in the innovation process. In later stages of 
the NPD process it is essential to ensure efficient exploitation of this new knowledge (Hafkesbrink and Schroll, 2009).

PSS entails a fundamental shift in market engagement (Mont, 2001). This means that exploration and exploitation practices should not be viewed as trade-offs between efficiency and flexibly, but a balance of synergic effects between two imperatives (He and Wong, 2016). In so doing, PSS contributes to reduced environmental loads in terms of product usage and increased resource productivity (Krucken and Meroni, 2006) by systematic management and incremental upgrading of product, process and service innovation (Maxwell and van der Vorst, 2003) whilst simultaneously seeking market opportunities for radical innovation (Baines et al, 2007).

\section{Insert table 1 here}

In summary, innovation demands attention to both existing knowledge and knowledge creation (Andriopoulos and Lewis, 2009). A product-service orientation involves sensing, seizing and reconfiguring capabilities for service innovation (Kindström and Kowalkowski, 2014). From this standpoint, as innovative efforts extend to the overall product life cycle, collaboration with supply chain partners and customers is essential during NPD (Liu et al, 2013). Innovation needs to be managed holistically in all phases of NPD, from discovery and development to commercialization and product maintenance (Martini et al, 2013).

\section{The theoretical proposition}

NPD is defined as a process of conceiving, creating, and launching a product new to the company, a market or the world (Crawford and Di Benedetto, 2003). It typically involves collaboration among scientists, engineers, industrial designers, market researchers and others (Veryzer 2005). The key phases in the process of NPD as presented by marketers are initiation,

which covers idea generation, screening and concept testing, and implementation, which includes product design, test marketing and market introduction (Sivakumar and Nakata, 2003).

Cooper's Stage-Gate process is the most widely used framework for structured NPD, as it incorporates both functional views and aims at suggesting practices, roles and responsibilities throughout the full NPD process. It is a "conceptual and operational model for moving a new product project from idea to launch" (Cooper, 2001:129). It breaks the innovation process into 
a predetermined set of stages (i.e. discovery, scoping, building the business case, development, testing and validation, and launch), each stage consisting of a set of prescribed, crossfunctional, and parallel activities. The entrance to each stage is a gate, which controls the process and serves as the quality control and go/kill checkpoint (Cooper, 2001; Cooper, 1994).

Based on the theoretical underpinnings discussed above, Figure 1 summarizes the theoretical framework for driving innovation through ambidextrous service provision. It is based on the presumption that product development is an iterative process that consists of four phases: a) generation, b) scoping, c) development and d) commercialisation. Traditional product development does not contain a service or aftermarket component, as that has largely been considered a separate function related to general maintenance rather than $R \& D$. In this framework however, it is proposed that in order to extend the life-cycle of the product and add value to the customer, provision of services must be integrated as a core part of product development (See table 1 for further evidence).

The main premise of including servitisation into the NPD process lies in the need to reduce cost, risk and waste for the manufacturer and create additional value for the customer. This ultimately leads to increased margins and customer loyalty for the provider and continuously improved products for the customer. This increases efficiency for the customer, reduces downtime and enables sustainable operations (Lee et al, 2012; Spangenberg et al, 2010).

The model makes the assumption that companies still explore their markets, products and potential new ideas within the early stages of NPD within the long life-cycle product environment. This means that by exploring even more radical approaches to their product portfolio, they can develop and evaluate potential expansions to their product range by exploring both service provision and product need. Lee et al, (2012) and Pham and Thomas, (2012) support the view that companies can seek new markets through effective product development. Not all of these explorations lead to new product developments, but they do build the knowledge base that feeds into future NPD or service provision. Product ideas that are fully scoped and in line with the strategic directions of the company are then exploited within development and commercialisation stages. Product and service provision that is integrated into the NPD process means strategically, the product and service portfolios become compatible with each other (Maxwell et al, 2006; Tukker and Tukker, 2006). Involving and 
exploiting aftermarket and services at this stage enables the company and the customer to develop a bespoke, customer-centred PSS that drives continuous collaboration and innovation. This is in line with Kindström and Kowalkowski (2014), who state that service design and delivery is dependent upon organizational innovations.

New capability requirements are identified through exploration activities and considered early in the process so that they can be sourced for effective exploitation stages. Creating the right culture is essential and involves the management of relationships within the service system and striking a balance between service and product (Kindström et al, 2013). This can be in the form of engaging further cross-functional collaboration or extending the early supplier involvement to buy the capability into the business. Lui et al, (2013) reinforce this point by stating that supply chain collaboration is essential during NPD. The gap between internal capabilities is addressed and augmented through continuous exploration and exploitation activities, with current and future customer needs built into the development processes and service provision. This is consistent with Juttner et al (2006) who found that for high value market segments involving a higher degree of customisation, an "agile" response was needed from suppliers (Jüttner et al, 2006, p.997). Companies can therefore build bundles of capabilities over time to serve the product-service system and ensure sustainable growth through continuous execution of $n$ NPD projects. Literature related to PSS supports sustainable solutions by providing systematic solutions consisting of product and services (Aurich et al, 2006) whereby the PSS system offers combinations of customer-focused goods, services and support (see for example, Fraça et al, 2017 Lui et al, 2013; Spangenberg, et al, 2010. Baines et al, 2007; Tukker and Tischner, 2006).

Ambidexterity of the service provision in the model is embodied in the structures in place that provide the search and prioritising of ideas as well as full exploitation of the customer need through continuous engagement of the full supply chain. Thus a product-service orientation is the management of sensing, seizing and reconfiguring capabilities for service innovation (Kindström et al, 2013). Companies can mitigate the cost and uncertainty of being ambidextrous through this managed process and ensure that the capabilities needed for continuous improvement are embedded within the culture of the company. In so doing the innovation process helps to improve employee skills and contributes to the development of core competences of the organization (Manda et al, 2016). 


\section{An illustrative case}

To illustrate the application of the proposed framework a Scottish manufacturing company is used as an example. The discussion aims to contribute to a body of knowledge on the role of services within product development that sustains competitiveness of manufacturers of complex long life-cycle products.

Consideration is also given to three sets of characteristics in the present case: first the coexistence of shortening time horizons for product development with long product life cycles; second the complementarity of initial hardware sales with after sales service and spare parts; and third the customization of end product to use needs.

Shortening product development times can be associated with shortening product life cycles, planned obsolescence and possibly overconsumption in so far as they help to displace incumbent products more rapidly. Bayus noted that many firms have implemented programs to shorten product development time because of the belief that product life cycles were shortening (1994, p.300: 1998, p.763). This in turn held important implications for consumers and society as a whole since it seemed to raise the possibility that both product and technological obsolescence was accelerating (Bayus, 1994, p.300). Consequently, shortening product development times in such cases could be an indicator of trends towards wasteful and premature product replacement.

Second, the complementarity of initial sale with after sale service leads to the dangers of the "razor and blade model" in which the initial sale is priced low or even at a loss, but profits are made from spare parts and after sales service. This can be a particular issue for long life product cycles, for example aero-engines can have life cycles spanning decades and the business model of engine manufacturers has traditionally been based on profit from high margins charged for maintenance and spare parts (Teece, 2010). There is a moral hazard aspect to this in so far as the suppliers in such markets can have an incentive to maximise the sales of spare parts and skimp on quality servicing once the initial sale has been made, which in turn could lead to wasteful and unnecessary premature junking of components over the life of the product.

Third, customization of products for specific customers can be a special case of the razor and blade model with what Williamson (1975) described as the "fundamental transformation" 
where a large number of competing suppliers ex ante contract are reduced to just one ex post the signing of the contract. This can reinforce the razor and blade model's dependency relationship with the supplier in which the interests of an opportunistic supplier can align more with junking of components than with careful and sustained maintenance.

Taking the foregoing into consideration it is clear that an integrated perspective of service provision requires changes in the business model. Circumstances where shortening product development times, the bundling of initial hardware sale with service and spares and bespoke or customised product design, can help delay product obsolescence, improve waste management and contribute to sustainable development (Liu et al., 2013), are analysed in this paper.

The company used to illustrate this case operates in power generation, petrochemicals, mining, steel making and cement manufacturing. The company has been going through a cycle of changes linked predominantly to establishing sustainable, repeatable and competitive product development procedures due to increased competition and evolving technology within their markets in the past decade,. This is aligned with their vision of becoming the leading application engineer providing lifetime solutions in air and gas handling.

However, the firm faces a variety of competitors in its markets which in general is composed of several major manufacturers and numerous niche players. The long product cycles which can characterise this sector can give time for market entry, heightened competition and eroded margins. In recent years some growing overseas markets have given opportunities for new product sales, while in other cases stagnation and recession has led to an emphasis on spare parts and service to avoid expensive capital expenditure on replacement products. But generally the strong competition that the firm can face in the markets in which it operates and the resulting pressure on product margins has led to an increased emphasis on post-sales service as a potential source of competitive advantage.

In turn, the need for a repeatable and bespoke product development procedure to fit with that strategy drove the company to engage with a Scottish University in a joint project aiming at developing the procedure to fit the changes in the global market place. The project was structured into four phases that included a situational analysis, development of the process in line with best practice, pilot implementation and full roll out. Within the second phase of the 
project it was established that the long life-cycle of their product heavily influenced the development process and thus should be considered as a central boundary condition within implementation. The core products of the business last over 50 years and the majority of the company's revenue was delivered by traditional technical aftersales support. The project team acknowledged that for the company to move forward the current business model needed to be reconsidered, and product development fully integrated in it with aftermarket services at the core of the process. Focussing on such service provision to serve the customer in partnership with the customer is in line with PSS literature.

\section{Insert figure 1 here}

The company piloted a 4-stage iterative product development procedure on selected strategic projects consistent with the framework proposed in Figure 1. One of the project ideas was related to monitoring performance of their products on-site, which was a direct result of structured generation and scoping phases of product development. By exploring customer needs and aftersales attributes of the product, the company was able to identify an innovation, related to a new market for the company.

In order to move forward with this project idea, a full scoping proposal was developed in line with preselected criteria and engagement with a cross-functional team that included aftermarket functions and the customer. Through this stage it was established that monitoring needed to be provided by the company to serve both the customer and the company's future development projects. Engagement with the aftermarket and the customer at this stage provided a robust case that was put forward to management. It resulted in the company acquiring a monitoring provider as the capabilities for this were lacking in-house.

The final result of this pilot project was a customer-centred product that delivered the core functionality, as well as the service relevant throughout the different stages of the product lifecycle. Through the monitoring system the relationship with the customer was maintained and necessary maintenance agreed based on the data captured. This ensured the product could be continuously improved without leaving the customer's site. For the case company the presence at the customer site provides rich data, enabling further value creation in both running and future projects. It also enables the customer to plan for maintenance and replacement as the performance of the product is monitored. The know-how created is shared by both the customer 
and the company, building a stronger relationship and enabling future collaboration and cocreation on incremental innovations related to operations of the product. Considering servitisation of the product in every stage of development here ensured that:

(a) The designed product fits the customer needs with a warranty agreed through the life-cycle of the product. This is important as it ensures that companies continue to innovate and support the customer while building their service provision capabilities (Gebauer and Friedli, 2005).

(b) Continuous improvement of the product is maintained through value in use. Customer insights are incorporated into new designs to reduce risk for both partners. In this way product stewardship is promoted within these long life-cycle products (Lightfoot et al, 2013), as the end of use for the product is considered at an early stage and all contingencies are put in place for recycling the product in its final life stages. This enables higher productivity to the company, and reduces the cost at the same time (Aurich et al, 2006). The relationship with the customer through co-creation and continuous service provision is further strengthened and the NPD process becomes more effective (Chesbrough and Sphorer, 2006).

(c) It also ensures that innovations are competence-based and enable the firm to stay on the existing technological trajectory. This helps support the competence-based process incorporating customer needs and supporting environmental sustainability through exploration and access to new materials, components and knowledge (Petrick and Echols, 2004).

The exploration activities associated with the iterative loops of Figure 1 represent the integration of old and new knowledge through incremental innovation. The learning process associated with the recombination of old, but useful knowledge, not only helps shorten the product development time that would otherwise be associated with new products, but as in any recycling process, also helps reduce the potential for waste and duplicated effort.

\section{Discussion}

The case shows that looking into service provision early in the life cycle has enabled the company to source the relevant capabilities that not only ensures an effective product, but will also help extend the product life-cycle and the relationship with customers. New knowledge has been created through this exploitation activity and integrated into the company's processes to inform and benefit future developments. This is strongly emphasised by the circular nature of the framework with iteration and integration at the core of achieving competitive advantage 
and efficient service provision. In so doing the right culture is created and involves the management of relationships within the service system and striking a balance between service and product (Kindström et al, 2013; Maxwell et al. 2006). The above demonstrates that exploration and exploitation of knowledge is integral to the NPD process and that ambidextrous service provision is a fundamental capability for PSS implementation (see Kindström et al, 2013; Lui et al, 2013; Spangenberg et al. 2010)

To present a balanced viewpoint we add some important caveats that may apply beyond the present case and the circumstances that the company faces at present. First, on the company strategy front, we note that there is no guarantee that commercial incentives will always align with policy imperatives as in the present case but can require an agile, ambidextrous organization to balance exploration and exploitation opportunities (Tushman and O'Reilly, 1996: O'Reilly and Tushman, 2013).

Second, on the policy and regulatory front, we are not arguing that any or all of shortening product development times, product/service tie-in, and customised product design will necessarily always have a benign impact in terms of promoting environmental sustainability. The threat of market failure, waste and environmental damage that each of these characteristics can entail and which were discussed in the introductory section still lurk in the background here.

The fact that the necessary technical knowhow is widely distributed and can be leveraged by numerous parties means that technology here is not only a source of growth but also helps maintain competitive balance and provide the commercial incentives that can help align supplier interests with those of the environment. But just as natural environments can be fragile, so also can be competitive environments. The most obvious threat in these respects could be a change in the competitive fabric of this sector, for example through a disruptive technology that leads to monopoly or concentration in the hands of a few dominant suppliers.

More generally, anything that disturbs the ecology of sustainable competition here can in turn harm both the interests of users and environmental sustainability. One such threat could come from the process of acquisition and consolidation that characterises some parts of the industry that the company is presently engaged in. A further danger that can be associated particularly with niche segments where direct competition may be muted is disclosure of technical information from supplier to buyer. Cebrián (2009) discusses moral hazard here in a licensing 
context where the licensor may economise on the expense of supplying their best engineers, or on the know-how transferred to the user. The informational disadvantage faced by the user in such cases can lead to failures to maintain the product properly, and/or overuse of spare parts and premature retirement of the product, all of which can contribute to environmental damage as well as product damage.

These last set of issues are potentially particularly relevant in the context of PSS where leasing has been seen as a means for extending the life cycle of products with the environmental benefit associated with slower obsolescence of products (Cooper, 2005). A potential environmental implication is that leasing can increase the consumption of capital goods by reducing initial outlays needed by the end user, while the moral hazard implications of users not owning can mean that the product depreciates faster and is scrapped sooner. Waldman (2003) also notes various historic cases where suppliers of durable goods allegedly used lease-only policies to scrap used units that were returned, a policy that would have been consistent with planned obsolescence (pp. 143-44). A further environmental downside which can be overlooked in the enthusiasm for leasing options for PSS is that lengthening product life might in some cases delay adoption of new and more fuel efficient technologies.

All these dangers are acknowledged. What we are suggesting is that cases involving the conditions that presently characterise this sector and the strategy of this company do not necessarily always involve trade-offs between private and public interest. We recognise there are still likely to be cases involving these conditions where fiscal, regulatory and stakeholder interventions may be necessary where there is a risk of commercial and social interests diverging.

We argue that Figure 1 illustrates virtuous circles of ambidexterity that support resolutions and provide mitigating strategies to issues relating to overconsumption of materials and resources (Fraça et al, 2017), such as dematerialisation and closed loop systems (Spangenberg et al, 2010).

Sensing, seizing and reconfiguring for ambidextrous service provision require organisational capabilities that anticipate disruptive technologies developed through the ongoing ambidextrous nature of the suggested NPD process (Hafkesbrink and Schroll, 2009). Literature discussing PSS implementation state the importance of collaboration and partnerships as PSS is based upon long-term relationships (Liu et al, 2013; Lee et al, 2012; Pham et al, 2012). The very nature of ambidextrous service provision highlights the importance of managing a 
portfolio of relationships as PSS requires multiple forms of partnerships and levels of engagement when managing networks relationships (Kindstrom et al, 2013)

\section{Conclusion and Contribution}

Returning to the research question "In what way can NPD process be refined to ensure sustainable servitization for long life-cycle products within high-tech environments", this paper demonstrates that both innovation and service provision should be integrated within the NPD process to ensure sustainable development of product-service systems. It builds a number of related and connected literature topics, PSS, sustainability, life-cycle management and StageGate NPD, but does not address detailed engagement with each stage of development.

Ambidexterity plays an important role within the framework as the exploration and exploitation activities help ensure continuous improvements of the company's offerings. This is particularly relevant for long-life cycle products where the aftermarket function serves as the main profit driver. Risks identified in the literature can be mitigated through this process as new offerings emerge from co-creation and continuous engagement with the supply chain and extended company networks. At the same time, complacency as to the benign effects of such strategies on environmental sustainability has to be caveated with recognition that they may be vulnerable to damage or erosion in the event of material changes in the competitive environment or the seller/buyer transactional arrangements.

The conceptual framework, intended for discussion illustrated by a single case, showcases how a structured, iterative approach can support implementation of product service systems. Contributions can be noted as follows:-

First, this paper contributes to the body of knowledge innovation and sustainability literatures through acknowledging the importance of both exploration and exploitation within NPD processes. We highlight that although literature on PSS emphasises the importance of sustainability, there are only a few tools or methods that fit with a product-service view. Our conceptual framework contributes to this by offering a means to understand where in the product development process sustainability criteria are embedded. That is at the concept generation and scoping phases as it is at these stages that most of the environment, social and cost factors for a product are determined (Maxwell and van der Vorst, 2003). These early stages involve exploration to assess dynamics upstream and downstream over the longer term in order to define customer needs, technologies and sustainability assessments to be incorporated into 
early design. On-going life cycle modifications take place during the development and commercialisation stages of the NPD process. This requires an appreciation of incremental innovation to extract more of the assets in-use as well as an understanding of when to scrap or make major changes (Mont, 2001). That is the exploitation of internal knowledge, capabilities and resources specifically related to portfolio management and risk analysis.

Second, it further provides a conceptual framework that demonstrates the connection between NPD and sustainable service provision. By adopting an ambidextrous service provision approach, the iterative processes and feedback loops illustrated in Figure 1 become established in organizational routines to support the development of new product and service offerings. Over time, exploratory learning is accumulated and embedded and within NPD process routines. That is developing the ability to explore new business opportunities and exploit existing competences as the same time.

In summary, the present case study and illustrative framework presume three sets of characteristics that support the concept of ambidextrous service provision in PSS:

(a) Shortening product development times. A structured and managed NPD process incorporating iterative process of exploration and exploitation supports a trend towards cost and waste reduction (Kindström and Kowalkowski, 2014). Collaboration begins at the design stage with access to external stakeholder competences required to develop service related capabilities (Fraça et al, 2017; Lee et al, 2013). Early design involvement is a pre-requisite and a critical competence for PSS provision as potential sustainability gains can be explored at the design stage (Spangenberg et al, 2010; Morelli, 2006; Tuckker and Tischner, 2006).

(b) Bundling initial hardware with service offerings. Innovative offerings can be developed by recombining and integrating service components and products (Kindström et al. 2013). Productivity and resources utilisation is improved through continuous product life cycle assessments and product stewardship is assisted by service contracts. The focus of the innovation strategy shifts from designing and selling physical products to designing a system of products and services (Manzini and Vezzoli, 2003). 
(c) Customized product design and contribution to waste management. PSS provides an opportunity to create unique and customized client relationships Maxwell et al, 2006; Aurich et al, 2006). PSS focuses on customer needs and in so doing increases the opportunities to find sustainable options (Tukker and Tischner, 2006). Reducing material flow lowers the environmental burden and assumes that changes can be realised by assessing the monetary value of economic, technical, service and social benefits to the customer ( (Mont, 2001); Brady et al, 2005).

Overall the theoretical proposition suggests that the relationships involved in helping to create the environmentally sensitive ambidextrous organization may be related to structured NPD, where value is created through continuous improvement and management of cost and waste. Growth is also driven through exploration of service provision at early life cycle stages of the NPD process.

\section{References}

D.L. Alting, D.J. Jørgensen, The life cycle concept as a basis for sustainable industrial production, Annals of the CIRP, 42(1) (1993) 163-167.

D. L. Alting, J. B. Legarth, Life Cycle Engineering and Design, Annals of the CIRP, 44(2) (1995) 69-580.

C. Andriopoulos, M.W. Lewis, Exploitation-exploration and organizational Ambidexterity: Managing paradoxes of innovation, Organization Science, 20(4) (2009) 696-717.

J. C. Aurich, C. Fuchs, C. Wagenknecht, Life cycle oriented design of technical ProductService Systems. Journal of Cleaner Production, 14(17) (2006) 1480-1494.

T.S. Baines, H.W. Lightfoot, S. Evans, A. Neely, R. Greenough, J. Peppard, R. Roy, E. Shehab, A. Braganza, A. Tiwari, J.R. Alcock, J.P. Angus, M. Basrl, A. Cousens, P. Irving, M. Johnson, J. Kingston, H. Lockett, V. Martinez, P. Michele, D. Tranfield, I.M. Walton, H. Wilson, Stateof-the-art in product-service systems. Proceedings of the Institution of Mechanical Engineers, Part B: Journal of Engineering Manufacture, 221(10) (2007) 1543-1552. 
N. J. Barnett, G. Parry, M. Saad, L. B. Newnes, Y. M. Goh, Servitization: is a paradigm shift in the business model and service enterprise required?. Strategic Change, 22(3-4) (2013) 145156.

B. L. Bayus, Are product life cycles really getting shorter?. Journal of Product Innovation Management, 11(4) (1994) 300-308.

B. L. Bayus, An analysis of product lifetimes in a technologically dynamic industry. Management Science, 44(6) (1998) 763-775.

T. Brady, A. Davies, D.M. Gann, Creating value by delivering integrated solutions, International Journal of Project Management, 23, 2005, 360-365.

M. Cebrián, The structure of payments as a way to alleviate contractual hazards in international technology licensing. Industrial and Corporate Change, 18(6) (2009) 1135-1160.

H. Chesbrough, J. Spohrer, A research manifesto for services science, Communications of the ACM, (49) 7 (2006)142-156.

W. Cohen, D. Leventhal, Absorbtive capacity: A new perspective on learning and innovation, Administrative Science Quarterly, 29 (1990) 128-152.

T. Cooper, Slower consumption reflections on product life spans and the "throwaway society”. Journal of Industrial Ecology, 9(1-2) (2005) 51-67.

B. Doualle, K. Medini, X. Boucher, D. Brissaud, V. Laforest, Design of sustainable productservice systems (PSS): towards an incremental stepwise assessment method, $23^{\text {rd }}$ CIRP Conference on Life Cycle Engineering, Doi: 10.1016/j.procir.2016.04.074

E. Fang, R. W. Palmatier, J. B. E. Steenkamp, Effect of service transition strategies on firm value. Journal of Marketing, 72(5) (2008) 1-14.

J. R. Galbraith, Organizing to deliver solutions. Organizational Dynamics, 31(2) (2002) 194207. 
H. Gebauer, E. Fleisch, An investigation of the relationship between behavioral processes, motivation, investments in the service business and service revenue. Industrial Marketing Management, 36(3) (2007) 337-348.

H. Gebauer, T. Friedli, Behavioural implications of the transition process from products to services, Journal of Business and Industrial Marketing, (20)2 (2005) 70-80.

C.B. Gibson, J. Birkinshaw, The antecedents, consequences and mediating role of organizational ambidexterity, The Academy of Management Journal, (47)2 (2004) 209-226.

Z. He, P. Wong, Exploration vs. Exploitation: an empirical test of the ambidextrous hypothesis. Organization Science, 15(4) (2016) 481-494.

U. Jüttner, J. Godsell, M. G. Christopher, Demand chain alignment competence-delivering value through product life cycle management. Industrial Marketing Management, 35(8) (2006) 989-1001.

J. Hafkesbrink, M. Schroll, Ambidextrous organizational and individual competences in open innovation: the dawn of a new research agenda. Journal of Innovation Management, 2 (1) (2014) 9-46.

I. V. Kastalli, B. Van Looy, Servitization: Disentangling the impact of service business model innovation on manufacturing firm performance. Journal of Operations Management, 31(4) (2013) 169-180.

H. Lightfoot, T. Baines, P. Smart, The servitization of manufacturing: a systematic literature review of interdependent trends, International Journal of Operations and Product Management, (33)11/12 (2013),1408-1434.

C.H. Liu, M.C. Chen, Y.H. Tu, C.C. Wang, Constructing a sustainable service business model, International Journal of Physical Distribution and Logistics Management, (44)1/2 (2014) 8097.

K.B.M. Manda, H. Bosch, S. Karanam, H. Beers, H. Bosman, E. Reitveld, E. Worrell, M.K. Patel, Value creation with life cycle assessment: an approach to contextualize the application 
of life cycle assessment in chemical companies to create sustainable value, Journal of Cleaner Production, 126 (2016) 337-351.

E.Manzini, C. Vezzoli, A strategic design approach to develop sustainable product service systems: examples taken from the 'environmentally friendly innovation'Italian prize. Journal of Cleaner Production, 11(8) (2003) 851-857.

J. G. March Exploration and exploitation in organisational learning. Organisational Science, (2)1 (1991) 71-87.

A. Martini, B.T. Laugen, L. Gastaldi, and M., Corso, Continuous innovation: Towards a paradoxical, ambidextrous combination of exploration and exploitation, International Journal of Technology Management, (61)1 (2013) 1-22.

D. Maxwell, R. van der Vorst, Developing sustainable products and services, Journal of Cleaner Production, 11 (2003) 883-985.

D. Maxwell, W. Sheate, R. van der Vorst, Functional and systems aspects of the sustainable product and service development approach for industry, Journal of Cleaner Production, 14 (2006) 1466-1479.

O. Mont, Clarifying the concept of product service systems, Journal of Cleaner Production, (11)8 (2001) 237-245.

N. Morelli, Developing new product service systems (PSS): methodologies and operational tools, Journal of Cleaner Production, 14 (2006) 1495-1501.

A. Neely, Exploring the financial consequences of the servitization of manufacturing. Operations Management Research, 1(2) (2008) 103-118.

C. A. O'Reilly, M. L.Tushman, Organizational ambidexterity: Past, present, and future. The Academy of Management Perspectives, 27(4) (2013) 324-338. 
I. J. Petrick, A. E. Echols, Technology road mapping in review: A tool for making sustainable new product development decisions. Technological Forecasting and Social Change, 71(1), (2004). 81-100.

D.T. Pham, A.J. Thomas, Fit manufacturing: A framework for sustainability, Journal of Manufacturing Technology, (23)1 (2012) 103-123.

S. Raisch, J. Birkinshaw, G. Probst, and L.M. Tushman, Organizational ambidexterity: balancing exploitation and exploration for sustained performance, Organization Science, (20)4 (2009) 685-695.

W. Reim, V. Parida, D. Örtqvist, Product-service systems (PSS) business models and tactics - systematic literature review, Journal of Cleaner Production, 97 (2015) 61-75.

T. O. Salge, T. Farchi, M. I., Barrett, S. Dopson, When Does Search Openness Really Matter? A Contingency Study of Health-Care Innovation Projects. Journal of Product Innovation Management, 30(4) (2013) 659-676.

G. Schuh, G. Gudergan, B.A. Feige, A. Buschmeyer, D. Krechting, $7^{\text {th }}$ Indsutrial Product Service Systems Conference-PSS industry transformation for sustainability and business. Doi:10.1016/j.procir.2015.02.133

J.H. Spangenberg, A. Faud-Luke, K. Blincoe, Design for sustainability: the interface of sustainable production and consumption, Journal of cleaner production, Vol. 18 (2010) 14851493.

M. Stoughton, T. Votta, Implementing service-based chemical procurement: lessons and results, Journal of Cleaner Production, 11 (2003) 839-849.

P. L. Swan, Optimum durability, second-hand markets, and planned obsolescence. Journal of Political Economy, 80(3) (1972) 575-585.

D. J. Teece, Profiting from technological innovation: Implications for integration, collaboration, licensing and public policy. Research Policy, 15(6) (1986) 285-305. 
D. J. Teece, Business models, business strategy and innovation. Long Range Planning, 43(2) (2010) 172-194.

A. Tukker, U. Tischner, Product-services as a research field: past, present and future. Reflections from a decade of research. Journal of Cleaner Production, 14(17) (2006) 15521556.

M. L. Tushman, C. A. O'Reilly, The ambidextrous organizations: managing evolutionary and revolutionary change. California Management Review, 38(4) (1996) 8-30.

M. Waldman, Durable goods theory for real world markets. The Journal of Economic Perspectives, 17(1) (2003) 131-154.

E. Westkämper, L. Alting, Arndt, Life Cycle Management and Assessment: Approaches and visions towards sustainable manufacturing, Keynote Paper. CIRP Annals - Manufacturing Technology, 49(2) (2000) 501-526.

O. E. Williamson, The logic of economic organization. Journal of Law, Economics, \& Organization, 4(1) (1988) 65-93. 
Table 1: Common links within the literature.

\begin{tabular}{|c|c|c|c|c|c|c|}
\hline Citation & PSS & $\begin{array}{c}\text { Sustainability } \\
\text { and } \\
\text { Stewardship }\end{array}$ & Design & Life Cycle & $\begin{array}{l}\text { Innovation and } \\
\text { NPD }\end{array}$ & Strategic Implications \\
\hline Fraça et al, 2017 & $\begin{array}{l}\text { PSS approach } \\
\text { proposed as an } \\
\text { opportunity to } \\
\text { support } \\
\text { sustainability. }\end{array}$ & $\begin{array}{l}\text { Product } \\
\text { stewardship is } \\
\text { assisted by } \\
\text { service contracts } \\
\text { and facilitates } \\
\text { efficient use of } \\
\text { resources. }\end{array}$ & $\begin{array}{l}\text { Early design } \\
\text { involvement is a } \\
\text { pre-requisite }\end{array}$ & $\begin{array}{l}\text { Life-cycle } \\
\text { assessment } \\
\text { included } \\
\text { throughout the } \\
\text { product life- } \\
\text { cycle, }\end{array}$ & $\begin{array}{l}\text { PSS approach } \\
\text { may be include } \\
\text { business model } \\
\text { innovation. }\end{array}$ & $\begin{array}{l}\text { Business model innovation generally fails to } \\
\text { embrace sustainability dimensions } \\
\text { Supports business model innovation and } \\
\text { design for strategic sustainable development. } \\
\text { Value propositions comprise bundles of } \\
\text { products and services that create value for } \\
\text { specific customer needs. } \\
\text { Essential to explore customer needs and } \\
\text { evaluate consumer segments and new markets. } \\
\text { PSS requires multiple forms of partnerships } \\
\text { and levels of engagement when managing } \\
\text { networks relationships. }\end{array}$ \\
\hline $\begin{array}{l}\text { Kindström and } \\
\text { Kowalkowski, } \\
2014 \\
\text { Kindström and } \\
\text { Kowalkowski, } \\
\text { Sandberg, 2013 }\end{array}$ & $\begin{array}{l}\text { A product- } \\
\text { service } \\
\text { orientation is } \\
\text { the management } \\
\text { of sensing, } \\
\text { seizing and } \\
\text { reconfiguring } \\
\text { capabilities for } \\
\text { service } \\
\text { innovation }\end{array}$ & $\begin{array}{l}\text { Improves } \\
\text { productivity and } \\
\text { resource } \\
\text { utilisation. }\end{array}$ & $\begin{array}{l}\text { Need to access } \\
\text { external } \\
\text { stakeholder } \\
\text { competences } \\
\text { and develop } \\
\text { service related } \\
\text { capabilities. }\end{array}$ & $\begin{array}{l}\text { Managers } \\
\text { need to } \\
\text { understand the } \\
\text { firms core } \\
\text { technological } \\
\text { capabilities } \\
\text { and its } \\
\text { marketing } \\
\text { capabilities. }\end{array}$ & $\begin{array}{l}\text { Use existing } \\
\text { capabilities } \\
\text { efficiently } \\
\text { (exploitation). } \\
\text { Create new } \\
\text { offerings and } \\
\text { market spaces that } \\
\text { stretch } \\
\text { capabilities } \\
\text { (exploration) }\end{array}$ & $\begin{array}{l}\text { Innovative offerings can be developed by } \\
\text { recombining and integrating service } \\
\text { components and products. } \\
\text { Relationship building is essential. } \\
\text { Creating the right culture involves the } \\
\text { management of relationships within the } \\
\text { service system and striking a balance between } \\
\text { service and product. } \\
\text { Service design and delivery is dependent upon } \\
\text { organizational innovations. }\end{array}$ \\
\hline Liu et al, 2013 & $\begin{array}{l}\text { PSS is defined } \\
\text { as offering } \\
\text { bundles of }\end{array}$ & $\begin{array}{l}\text { Improves } \\
\text { productivity and } \\
\text { reduces waste. }\end{array}$ & $\begin{array}{l}\text { Collaboration } \\
\text { begins at design } \\
\text { stage }\end{array}$ & $\begin{array}{l}\text { Collaboration } \\
\text { continues until }\end{array}$ & $\begin{array}{l}\text { Supply chain } \\
\text { collaboration }\end{array}$ & $\begin{array}{l}\text { New business model optimizes customer's } \\
\text { business operations. }\end{array}$ \\
\hline
\end{tabular}




\begin{tabular}{|c|c|c|c|c|c|c|}
\hline Citation & PSS & $\begin{array}{l}\text { Sustainability } \\
\text { and } \\
\text { Stewardship }\end{array}$ & Design & Life Cycle & $\begin{array}{l}\text { Innovation and } \\
\text { NPD }\end{array}$ & Strategic Implications \\
\hline & $\begin{array}{l}\text { customer- } \\
\text { focused } \\
\text { combinations of } \\
\text { goods, services } \\
\text { and support. }\end{array}$ & & & $\begin{array}{l}\text { the end of } \\
\text { PLC }\end{array}$ & $\begin{array}{l}\text { during NPD } \\
\text { essential. . }\end{array}$ & $\begin{array}{l}\text { Relational based services. Wide reach and } \\
\text { collaboration with supply chain and customers } \\
\text { is required. }\end{array}$ \\
\hline $\begin{array}{l}\text { Lee et al, } 2012 \\
\text { Pham and } \\
\text { Thomas, } 2012\end{array}$ & $\begin{array}{l}\text { A system of } \\
\text { products, } \\
\text { services, } \\
\text { networks of } \\
\text { players and } \\
\text { supporting } \\
\text { infrastructure } \\
\text { that strives to be } \\
\text { competitive, } \\
\text { satisfy customer } \\
\text { needs and } \\
\text { reduce } \\
\text { environmental } \\
\text { impact. P.174 }\end{array}$ & $\begin{array}{l}\text { PSS explores } \\
\text { sustainable } \\
\text { solutions. } \\
\text { Economic, } \\
\text { environmental } \\
\text { and social } \\
\text { dimensions need } \\
\text { to be considered } \\
\text { when evaluating } \\
\text { PSS. }\end{array}$ & & $\begin{array}{l}\text { Managing } \\
\text { resources } \\
\text { through the } \\
\text { PLC can } \\
\text { contribute to } \\
\text { reducing } \\
\text { environmental } \\
\text { impact. }\end{array}$ & $\begin{array}{l}\text { Companies can } \\
\text { seek new markets } \\
\text { through effective } \\
\text { product } \\
\text { innovation. }\end{array}$ & PSS is based upon long-term relationships. \\
\hline $\begin{array}{l}\text { Spangenberg et } \\
\text { al, } 2010\end{array}$ & $\begin{array}{l}\text { PSS improves } \\
\text { product } \\
\text { efficiency } \\
\text { through ongoing } \\
\text { maintenance } \\
\text { and service } \\
\text { provision. }\end{array}$ & $\begin{array}{l}\text { Eco-efficiency } \\
\text { through } \\
\text { increased } \\
\text { product } \\
\text { efficiency. } \\
\text { Social and } \\
\text { institutional } \\
\text { dimensions } \\
\text { include health } \\
\text { and safety, } \\
\text { labour etc. }\end{array}$ & $\begin{array}{l}\text { Design for } \\
\text { sustainability } \\
\text { build in early }\end{array}$ & $\begin{array}{l}\text { Based upon } \\
\text { life-cycle } \\
\text { analysis. }\end{array}$ & $\begin{array}{l}\text { Early involvement } \\
\text { in NPD essential }\end{array}$ & $\begin{array}{l}\text { Incorporate in vision and strategy. Seek } \\
\text { expertise beyond organisation. }\end{array}$ \\
\hline Baines et al, 2007 & $\begin{array}{l}\text { PSS is a special } \\
\text { case of } \\
\text { servitization. }\end{array}$ & $\begin{array}{l}\text { Use } \\
\text { technological } \\
\text { knowledge to }\end{array}$ & & & & $\begin{array}{l}\text { PSS competitive strategy uses deep product, } \\
\text { process and customer knowledge to reduce the } \\
\text { total cost of the product. }\end{array}$ \\
\hline
\end{tabular}




\begin{tabular}{|c|c|c|c|c|c|c|}
\hline Citation & PSS & $\begin{array}{c}\text { Sustainability } \\
\text { and } \\
\text { Stewardship }\end{array}$ & Design & Life Cycle & $\begin{array}{c}\text { Innovation and } \\
\text { NPD }\end{array}$ & Strategic Implications \\
\hline & & $\begin{array}{l}\text { reduce costs and } \\
\text { deliver better } \\
\text { value while } \\
\text { using less } \\
\text { energy or } \\
\text { materials. }\end{array}$ & & & & Provides strategic market opportunities. \\
\hline $\begin{array}{l}\text { Aurich et al, } 2006 \\
\text { Krucken and } \\
\text { Meroni, } 2006 \\
\text { Maxwell et al, } \\
2006 \\
\text { Morelli, } 2006 \\
\text { Tukker and } \\
\text { Tischner, } 2006\end{array}$ & $\begin{array}{l}\text { Provision of } \\
\text { systemic } \\
\text { solutions } \\
\text { consisting of } \\
\text { products and } \\
\text { services. } \\
\text { PSS are } \\
\text { specific types of } \\
\text { value } \\
\text { propositions that } \\
\text { a business } \\
\text { (network) offers } \\
\text { to (co-produces) } \\
\text { its clients } \\
\text { (p1552) }\end{array}$ & $\begin{array}{l}\text { PSS contribute } \\
\text { to reduced } \\
\text { environmental } \\
\text { loads in terms of } \\
\text { product usage } \\
\text { and increased } \\
\text { resource } \\
\text { productivity. } \\
\text { PSS focuses on } \\
\text { a need to be } \\
\text { fulfilled and in } \\
\text { so doing } \\
\text { increase the } \\
\text { opportunities to } \\
\text { find sustainable } \\
\text { options. }\end{array}$ & $\begin{array}{l}\text { Designers guide } \\
\text { the sense } \\
\text { making process } \\
\text { Design } \\
\text { competencies } \\
\text { are critical for } \\
\text { PSS provision } \\
\text { Potential } \\
\text { sustainability } \\
\text { gains can be } \\
\text { explored at the } \\
\text { design stage. }\end{array}$ & $\begin{array}{l}\text { PLC begins } \\
\text { with design }\end{array}$ & $\begin{array}{l}\text { There is an } \\
\text { assumption that } \\
\text { changes can be } \\
\text { realised through } \\
\text { untapped potential } \\
\text { for an economic/ } \\
\text { environmental/ } \\
\text { social win-win. }\end{array}$ & $\begin{array}{l}\text { PSS is fundamental to the provision of } \\
\text { solution orientated partnerships. } \\
\text { PSS provides an opportunity to create unique } \\
\text { and customized client relationships. } \\
\text { At the strategic level, the product and service } \\
\text { portfolios need to be compatible with each } \\
\text { other and integrated. }\end{array}$ \\
\hline Brady et al. 2005 & $\begin{array}{l}\text { Provision of } \\
\text { solutions rather } \\
\text { than individual } \\
\text { products and } \\
\text { services. }\end{array}$ & $\begin{array}{l}\text { Assess } \\
\text { monetary value } \\
\text { of economic, } \\
\text { technical, } \\
\text { service and } \\
\text { social benefits } \\
\text { to the customer. }\end{array}$ & $\begin{array}{l}\text { Design skills } \\
\text { include the } \\
\text { ability to spot } \\
\text { when new value } \\
\text { can be added } \\
\text { due to } \\
\text { technology } \\
\text { changes. }\end{array}$ & $\begin{array}{l}\text { Extend } \\
\text { lifecycle to } \\
\text { extract more } \\
\text { from the asset } \\
\text { in use or } \\
\text { decide when } \\
\text { to scrap or } \\
\text { modify. }\end{array}$ & $\begin{array}{l}\text { Promotes the } \\
\text { development new } \\
\text { ways for } \\
\text { components to } \\
\text { work together. } \\
\text { Innovation } \\
\text { management is a } \\
\text { key skill. }\end{array}$ & $\begin{array}{l}\text { Providers take over the risk and responsibility. } \\
\text { Providers understand how value is created } \\
\text { through the eyes of the customer. } \\
\text { PSS requires long term strategic partnerships } \\
\text { with customers. }\end{array}$ \\
\hline
\end{tabular}




\begin{tabular}{|c|c|c|c|c|c|c|}
\hline Citation & PSS & $\begin{array}{c}\text { Sustainability } \\
\text { and } \\
\text { Stewardship }\end{array}$ & Design & Life Cycle & $\begin{array}{c}\text { Innovation and } \\
\text { NPD }\end{array}$ & Strategic Implications \\
\hline $\begin{array}{l}\text { Manzini and } \\
\text { Vezzoli, } 2003 \\
\text { Maxwell and van } \\
\text { der Vorst, } 2003 \\
\text { Stoughton and } \\
\text { Votta, } 2003\end{array}$ & $\begin{array}{l}\text { An innovation } \\
\text { strategy, } \\
\text { shifting focus } \\
\text { from designing } \\
\text { and selling } \\
\text { physical } \\
\text { products to } \\
\text { designing a } \\
\text { system of } \\
\text { products and } \\
\text { services. }\end{array}$ & $\begin{array}{l}\text { Material } \\
\text { management } \\
\text { and process } \\
\text { efficiency can } \\
\text { yield greater } \\
\text { margins. } \\
\text { Elimination of } \\
\text { hazardous } \\
\text { materials, waste } \\
\text { reduction }\end{array}$ & $\begin{array}{l}80 \% \text { of environ- } \\
\text { mental, social } \\
\text { and cost factors } \\
\text { are determined } \\
\text { at the design } \\
\text { phase. }\end{array}$ & $\begin{array}{l}\text { Life cycle } \\
\text { costs are } \\
\text { reduced in } \\
\text { terms of } \\
\text { material, } \\
\text { labour and } \\
\text { waste } \\
\text { management }\end{array}$ & $\begin{array}{l}\text { On-going } \\
\text { upgrading product } \\
\text { and process } \\
\text { innovation. }\end{array}$ & $\begin{array}{l}\text { Requires the ability to assess upstream and } \\
\text { downstream dynamics. Share information in a } \\
\text { more open and informal way and understand } \\
\text { customer needs. } \\
\text { A strategic process that results in new forms } \\
\text { of organization and innovative forms of co- } \\
\text { production of value. } \\
\text { Realises economic, environmental and social } \\
\text { benefits. A business model based on long-term } \\
\text { contracts. }\end{array}$ \\
\hline Mont, 2001 & $\begin{array}{l}\text { Utility through } \\
\text { use of services } \\
\text { rather than } \\
\text { products. } \\
\text { Value is added } \\
\text { through non- } \\
\text { material aspects } \\
\text { of products. }\end{array}$ & $\begin{array}{l}\text { Reducing } \\
\text { material flow } \\
\text { lowers environ- } \\
\text { mental burden. }\end{array}$ & $\begin{array}{l}\text { Design } \\
\text { integrated into } \\
\text { products. }\end{array}$ & $\begin{array}{l}\text { Providers are } \\
\text { involved and } \\
\text { responsible } \\
\text { through life } \\
\text { cycle phases. }\end{array}$ & $\begin{array}{l}\text { Facilitates } \\
\text { innovation. }\end{array}$ & $\begin{array}{l}\text { New market opportunities sought. } \\
\text { Trade-offs between external co-operation and } \\
\text { internal environmental management. } \\
\text { There is a Fundamental shift in market } \\
\text { engagement. }\end{array}$ \\
\hline
\end{tabular}




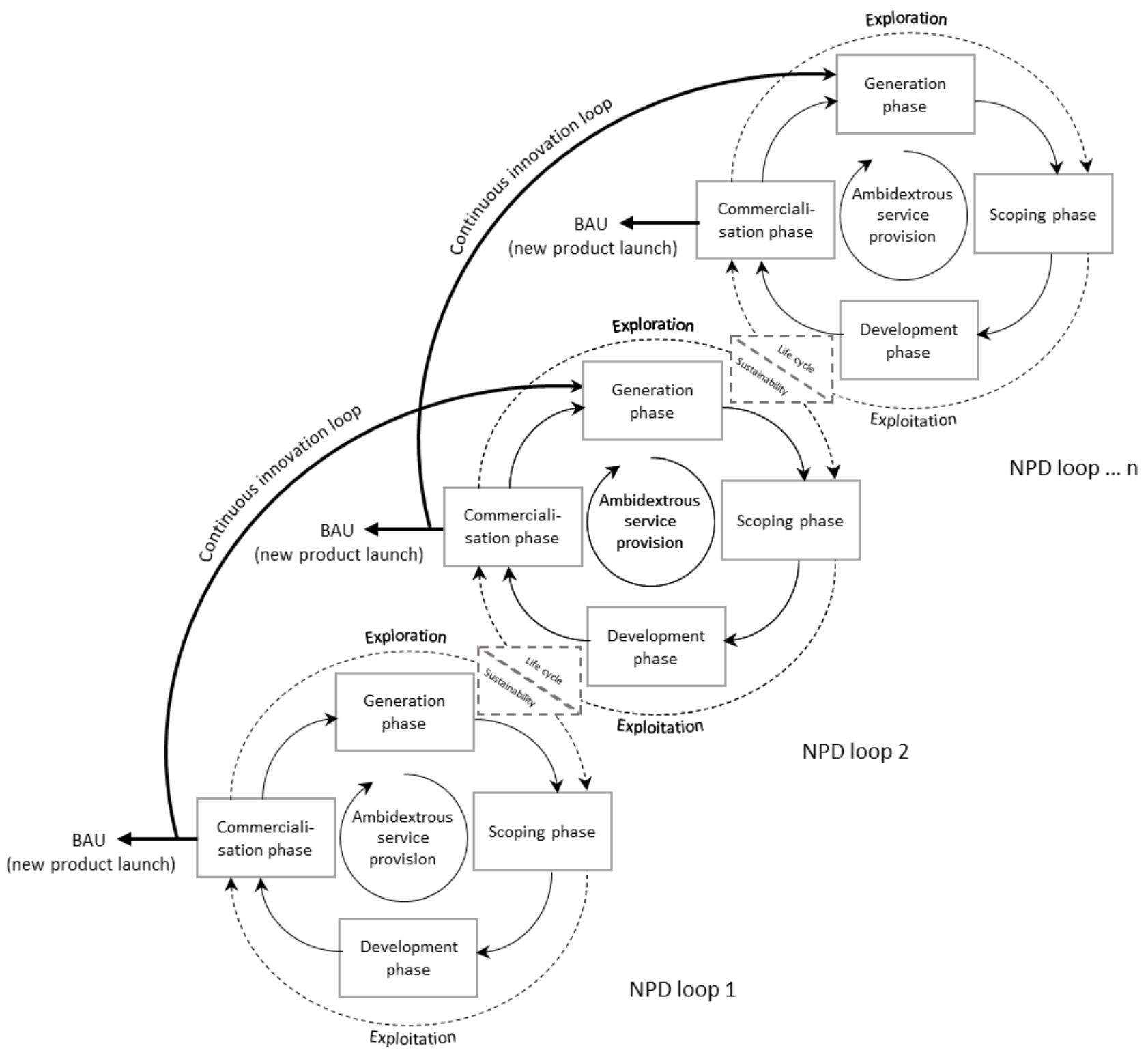

\section{Figure 1: Driving innovation through ambidextrous service provision}

(source: authors) 